\title{
EFFECT OF IRRIGATION INTERVALS AND PK FERTILIZER LEVELS ON PEANUT (Arachis hypogaea, L.) UNDER SANDY SOIL CONDITIONS
}

\author{
Abd El-Maksoud, M.F.; A.A. Mansour and A.H. Bassiouny \\ Plant Production Department, Efficient Productivity Institute, Zagazig University, \\ Egypt.
}

\section{ABSTRACT}

The influences of irrigation at three intervals (every 4, 6 and 8 days), potassium at three rates (24, 48 and $\left.72 \mathrm{~kg} \mathrm{~K} \mathrm{~K}_{2} \mathrm{O} / \mathrm{fad}\right)$ and phosphorus at three rates $\left(15,30\right.$ and $45 \mathrm{~kg} \mathrm{P}_{2} \mathrm{O}_{5} /$ fad) on yield, yield components and seed quality of peanut cultivar Giza 5 were studied in a private farm at El-Salhya region, Sharkia Governorate during summer seasons of 2006 and 2007.

Results show that either irrigation or fertilization treatments affected significantly all studied characters. Decreasing irrigation intervals from 8 to 6 and then to 4 days, increasing $K$ fertilizer levels from 24 to 48 and then to $72 \mathrm{~kg} \mathrm{~K}_{2} \mathrm{O} /$ fad and increasing $\mathrm{P}$ fertilizer levels from 15 to 30 and then to $45 \mathrm{~kg} \mathrm{P}_{2} \mathrm{O}_{5} /$ fad increased significantly plant height, number of branches/plant, number of pods/plant, seed yield/plant, 100-pod weight, shelling percentage, pod, seed and foliage yields/fad. However, oil and protein percentages significantly increased by any increase of $K$ or $P$ fertilizer, but with respect to irrigation treatments, the highest oil percentage was attained when the irrigation intervals were at 4 or 8 days with no significant effect on protein percentage.

The interaction effect between irrigation intervals and $K$ fertilizer levels on 100-pod weight and seed yield/fad as well as the interaction effect between irrigation intervals and $P$ fertilizer levels on 100-pod weight and foliage yield/fad were significant. Irrigation every 4 days under $72 \mathrm{~kg} \mathrm{~K} \mathrm{~K}_{2} \mathrm{O} / \mathrm{fad}$ or $45 \mathrm{~kg} \mathrm{P}_{2} \mathrm{O}_{5} /$ fad gave the heaviest 100- pod weight and highest seed yield/fad. Foliage yield/fad were the highest with 4 days irrigation interval when 30 or $45 \mathrm{~kg} \mathrm{P}_{2} \mathrm{O}_{5} /$ fad were applied.

Significant and positive correlation coefficients were detected between seed yield/fad and all studied characters, while 
Key words: Irrigation intervals, pk fertilizer levels, peanut (arachis hypogaea, 1 .), sandy soil.

\section{INTRODUCTION}

Peanut (Arachis hypogaea, L.) is one of the most important oil crops grown successfully in Egypt not only for oil production, but also for fresh human consumption or for export. The increase of peanut production requires an effective production plan, and the cultural practices must be effectively integrated into the total peanut production plan to increase yield and quality of peanut.

Irrigation (amount and timing) is still the key to a successful peanut crop under reclaimed sandy soil conditions and appeared to be a considerable factor affecting peanut economic production. Sakr et al. (1996) reported that increasing irrigation interval decreased significantly plant height, number of branches/plant, number of pods/plant, 100-pod weight, 100 -seed weight, shelling percentage and oil and protein contents. Also, they found that the 5 days interval may be the optimum for peanut production, Amir et al. (2005) stated that peanut plants with adequate water irrigation not only has given more kernels, but also highest levels of total protein. Also, they found that oil content increased as the amount of water increased. Plout and Ben-Hur (2005) studied three irrigation frequency treatments i.e. every 3, 7 and 10 days during flowering and pod-filling stages and found that the differences in peanut pod yield due to irrigation were not significant.

Regarding to K fertilizer application, Anton and Bassiem, (1998); Dahdouh, (1999) and Darwich et al. (2002) found that adding $48 \mathrm{~kg}$ $\mathrm{K}_{2} \mathrm{O} /$ fad significantly increased each of plant height, number of pods/plant, weight of pods and seeds/plant, 100-seed weight, yield of pods and seeds/fad. Moreover, El-Far and Ramadan (2000) observed that application of $36 \mathrm{~kg} \mathrm{~K} 2 \mathrm{O} /$ fad significantly increased each of pod weight/plant, 100-seed weight, shelling percentage and pod yield/fad. Also, Ali and Mowafy (2003), showed that K fertilizer significantly increased each of plant height, number of pods/plant, weight of pods and seeds/plant, 100-seed weight, pod and seed yields/fad, shelling percentage and fodder yield/fad. Asmaa Khameis (2003) observed a significant increase in each of plant height, pod and seed weight/plant and yields/fad of peanut due to adding $50 \mathrm{~kg}$ 
$\mathrm{K}_{2} \mathrm{O} /$ fad. Finally, Maha Abd Alla (2004) reported that increasing $\mathrm{K}$ fertilizer from 24 to 48 and $72 \mathrm{~kg} \mathrm{k} \mathrm{k}_{2} \mathrm{O} /$ fad tended to increase the yield and yield attributes of peanut. Similar results were recorded by Nasr-Alla et al. (1998), Migawer-Ekram and Mona Soliman (2001) and Saleh et al. (2003).

With respect to phosphorus fertilization, Attia (2004) showed that peanut pod and seed yields/fad as well as yield attributes significantly increased with increasing $\mathrm{P}$ levels up to $45 \mathrm{~kg} \mathrm{P}_{2} \mathrm{O}_{5} /$ fad. Moreover, NasrAlla et al. (1998) and Migawer-Ekram and Mona Soliman (2001) with peanut grown in newly reclaimed loamy sandy soil, found that increasing $\mathrm{P}$ rates up to $30 \mathrm{~kg} \mathrm{P}_{2} \mathrm{O}_{5} /$ fad significantly increased pod and seed yields / fad and their attributes and resulted in acceptable oil and protein contents. However, Mirvat et al. (2006) mentioned that adding P fertilizer up to $60 \mathrm{~kg}$ $\mathrm{P}_{2} \mathrm{O}_{5} /$ fad significantly increased yield and its components as well as protein content of peanut, while oil percentage insignificantly affected by $\mathrm{P}$ fertilizer rates. Similar results were obtained by El-Far and Ramadan (2000), El-Shahat (2001), Darwish et al. (2002), Ali and Mowafy (2003), Yasein (2005) and Ash-Shormillesy-Salwa and Abd El-Hameed (2006).

Therefore, the aim of this work was to study the effect of irrigation intervals, phosphorus and potassium fertilization on yield and its attributes of peanut under sandy soil conditions.

\section{MATERIALS AND METHODS}

Two field experiments were carried out at El-Salhya region, Fakous District, Sharkia Governorate, Egypt during two successive summer seasons of 2006 and 2007. The objective of this work was to investigate the effect of irrigation interval, potassium and phosphorus fertilization levels on yield, yield attributes and quality of Giza 5 peanut cultivar under cultivated sandy soil conditions.

A split- split plot design with four replicates was followed, three irrigation intervals $(8,6$ and 4 days) were assigned to the main plots. The sub-plots were allotted by three potassium fertilization levels (24, 48 and 72 $\mathrm{kg} \mathrm{K}_{2} \mathrm{O} /$ fad in the form of potassium sulphate $\left(48 \% \mathrm{~K}_{2} \mathrm{O}\right)$. The sub-subplots were occupied by three phosphorus fertilization levels $(15,30$ and $45 \mathrm{~kg}$ $\mathrm{P}_{2} \mathrm{O}_{5} /$ fad in the form of calcium super phosphate $\left(15.5 \% \mathrm{P}_{2} \mathrm{O}_{5}\right)$. $\mathrm{K}$ and $\mathrm{P}$ fertilizers were added just before sowing which was undertaken on May $21^{\text {st }}$ and $25^{\text {th }}$ in the $1^{\text {st }}$ and $2^{\text {nd }}$ seasons, respectively. The sub-subplot area was $16 \mathrm{~m}^{2}(4 \times 4 \mathrm{~m})$ included eight rows $50 \mathrm{~cm}$ apart, one plant /hill and $20 \mathrm{~cm}$ distance between hills. The preceding crop was wheat in the two seasons. 
The soil of experimental site is sandy in texture, it had an average $\mathrm{pH}$ of 8.8 and organic matter content of $0.27 \%$. The available $\mathrm{N}, \mathrm{P}$ and $\mathrm{K}$ contents were $36.41,5.27$ and $190.15 \mathrm{ppm}$, respectively (average over the two seasons for the upper $30 \mathrm{~cm}$ of soil depth). A basal dose of gypsum $(500 \mathrm{~kg} /$ fad) was applied during soil preparation, in addition to $30 \mathrm{~kg} \mathrm{~N}$ in the form of ammonium sulphate $(20.5 \% \mathrm{~N})$ applied in equal three doses at sowing, after 24 and 48 days from sowing. All cultural practices, except those under study, were kept the same as usually practiced in peanut fields.

At harvest, the following characters were estimated on ten guarded plants taken randomly from the third row of each plot in both seasons. 1Plant height $(\mathrm{cm}), 2$ - Number of branches/plant, 3- Number of pods/plant, 4Seed yield (gm/plant), 5-100-pod weight (g) and 6- Shelling (\%). In addition, the middle two rows were harvested from each plot to estimate 1Pod yield (kg/fad), 2- Seed yield (kg/fad) and 3- Foliage yield (t/fad).

Dried mature seeds were ground into very fine powder to determine oil percentage using Soxhelt method with diethyl ether as a solvent, while crude protein percentage was determined as a total nitrogen by Micro-kjeldahl method. Chemical analysis procedures used were followed as described by A.O.A.C. (1980).

Analysis of variance and combined analysis for the two seasons were carried out as described by Snedecor and Cochran (1982). The differences among treatments were compared using Duncan's multiple range test (Duncan, 1955), where means had the different letters were statistically significant, while those followed by the same letters were statistically insignificant. In the interaction Tables, capital and small letters were used to compare means in rows and columns, respectively. The combined analysis of variance of the two seasons was used to calculate the simple correlation coefficients as described by Svab (1973).

\section{RESULTS AND DISCUSSION}

\section{1- Plant height and number of branches/plant:}

Data presented in Table (1) show that prolonging irrigation interval from 4 to 6 or to 8 days caused a continuous and significant decrease in both plant height and number of branches/peanut plant. This was valid in the two growing seasons and the combined analysis, except the first season, where the decrease in plant height not reached the $5(\%)$ level of significance by prolonging irrigation from 4 to 6 days. Similar results were obtained by Sakr et al. (1996), Amir et al. (2005) and Plout and Ben-Hur (2005). 
J. Product. \& Dev., 14(1),2009 
Increasing of $\mathrm{K}$ fertilizer levels from 24 to 48 and up to $72 \mathrm{~kg}$ $\mathrm{K}_{2} \mathrm{O} /$ fad and $\mathrm{P}$ fertilizer rate from 15 to 30 and to $45 \mathrm{~kg}_{2} \mathrm{O}_{5} /$ fad was followed by a positive and significant increase in both plant height and number of branches /plant. This was true in both seasons and their combined. Similar results were reported by El-Far and Ramadan (2000), Ali and Mowafy (2003) and Maha Abd Alla (2004).

\section{2- Number of pods and seed weight (g) per plant:}

Data in Table (2) show that decreasing irrigation interval from 8 to 6 and down to 4 days caused a continuous and significant increases in both number of pods and seed weight/peanut plant. This was true in both seasons and their combined. In this respect, Shinde and Pawar (1982 and 1984) reported that, maximum values in number of pods and seed yield per plant were obtained under sandy soil conditions by irrigation every 4 days.

Regarding the response of pods number and seed weight per plant to $\mathrm{K}$ and $\mathrm{P}$ fertilization it is interesting to note that any increment of $\mathrm{K}$ and $\mathrm{P}$ fertilizer was followed by a significant increase in each of pods number and seed weight/peanut plant. This was true in both seasons and their combined. These data are in harmony with those reported in the literature on $\mathrm{K}$ fertilizer by Saleh et al. (2003) and Maha Abd Alla (2004) and on P fertilizer by El-Far and Ramadan, (2000) and Ali and Mowafy (2003).

\section{3-100-pod weight (g) and shelling percentage:}

Each decrease in irrigation interval from 8 to 6 and from 6 to 4 days was followed by a significant increase in both 100-pod weight and shelling percentage (Table 3). This was true in both seasons and their combined. These data clearly indicate that exposing peanut plants to drought caused a reduction in yield components. These results are supported by finding of Azab et al. (2004). They noted that irrigate peanut plant at 50\% depletion from field capacity gave the highest values of 100-pod weight and shelling percentage. Also, Sakr et al. (1996) obtained similar findings.

Increasing of $\mathrm{K}$ fertilizer from 24 to 48 and up to $72 \mathrm{~kg} \mathrm{~K}_{2} \mathrm{O} / \mathrm{fad}$ and $\mathrm{P}$ fertilizer rate from 15 to 30 and to $45 \mathrm{~kg} \mathrm{P}_{2} \mathrm{O}_{5} / \mathrm{fad}$ resulted in a significant increase in both 100- pod weight and shelling percentage. This was true in both seasons and their combined. Similar results were obtained on K fertilizer by Dahdouh (1999) and Asmaa Khameis (2003) and P fertilizer by Anton and Bassiem (1998) and Ali and Mowafy (2003).

The interaction effect between irrigation intervals and $\mathrm{K}$ fertilization levels on 100-pod weight was highly significant (Table 3). The heaviest 100-pod 
weight was recorded by irrigation every four days and application of $72 \mathrm{~kg}$ $\mathrm{K}_{2} \mathrm{O}$ / fad as shown in Table $3 \mathrm{a}$.

Also, the interaction effect between irrigation intervals and $\mathrm{P}$ fertilizer level on 100-pod weight was highly significant. The heaviest 100 pod weight was found by irrigation every four days and adding of $45 \mathrm{~kg}$ $\mathrm{P}_{2} \mathrm{O}_{5} /$ fad as shown in Table $3 \mathrm{~b}$.

Table 3-a : Effect of interaction between irrigation intervals and $\mathrm{K}$ fertilization levels on peanut 100-pod weight (g).

\begin{tabular}{cccc}
\hline & & & \\
Irrigation interval & $\mathbf{K}_{\mathbf{1}}$ & $\mathbf{K}_{\mathbf{2}}$ & $\mathbf{K}_{\mathbf{3}}$ \\
\hline $\mathbf{I}_{\mathbf{1}}$ & $\mathrm{C}$ & $\mathrm{B}$ & $\mathrm{A}$ \\
& $140.17 \mathrm{c}$ & $155.97 \mathrm{c}$ & $165.09 \mathrm{c}$ \\
\hline $\mathbf{I}_{\mathbf{2}}$ & $\mathrm{C}$ & $\mathrm{B}$ & $\mathrm{A}$ \\
& $151.66 \mathrm{~b}$ & $170.15 \mathrm{~b}$ & $182.20 \mathrm{~b}$ \\
\hline $\mathbf{I}_{3}$ & $\mathrm{C}$ & $\mathrm{B}$ & $\mathrm{A}$ \\
& $155.98 \mathrm{a}$ & $184.30 \mathrm{a}$ & $188.88 \mathrm{a}$ \\
\hline
\end{tabular}

Table 3-b : Effect of interaction between irrigation intervals and Pfertilization levels on peanut 100 -pod weight $(\mathrm{g})$.

\begin{tabular}{cccc}
\hline P-fertilizer levels & $\mathbf{P}_{\mathbf{1}}$ & $\mathbf{P}_{\mathbf{2}}$ & $\mathbf{P}_{\mathbf{3}}$ \\
\hline Irrigation interval & & $\mathrm{A}$ & $\mathrm{A}$ \\
$\mathbf{I}_{\mathbf{1}}$ & $\mathrm{B}$ & $\mathrm{A}$ & $156.93 \mathrm{c}$ \\
\hline $\mathbf{I}_{\mathbf{2}}$ & $149.02 \mathrm{~b}$ & $155.28 \mathrm{c}$ & $\mathrm{A}$ \\
& $\mathrm{C}$ & $\mathrm{B}$ & $176.44 \mathrm{~b}$ \\
\hline $\mathbf{I}_{3}$ & $158.40 \mathrm{~b}$ & $166.92 \mathrm{~b}$ & $\mathrm{~A}$ \\
& $\mathrm{C}$ & $\mathrm{B}$ & $186.26 \mathrm{a}$ \\
\hline
\end{tabular}

\section{4- Pod, seed and foliage yields per faddan:}

As shown in Table (4) pod, seed and foliage yields were significantly increased by irrigation every four days. This was true in both seasons and their combined. Similar results were obtained by Reddy et al. (1982) and Desai et al. (1992). Also, Shinde and Pawar (1982) reported that exposing peanut plants to moisture stress caused a reduction in seed yield 
and its components. Maximum values were obtained by irrigation every 4 days.

Increasing K-level up to $72 \mathrm{~kg} \mathrm{~K}_{2} \mathrm{O}_{2}$ / fad increased significantly pod, seed and foliage yields per fad. This was always true in both seasons and their combined. Similar findings were obtained by El-Far and Ramadan (2000) and Asmaa Khameis (2003). Response of pod, seed and foliage of peanut yields to $\mathrm{K}$ fertilization may be due to its role on nature of peanut growth and pegging has to be grown in light textural soil. This type of soil is characterized by being poor fertile soil. Also, potassium being a very mobile element and its content in sandy soil is poor, has to be applied too.

A clear cut effect of $\mathrm{P}$ fertilizer application was observed on pod, seed and foliage yields /fad. This is expected since similar effect on all the aforementioned characters in both seasons and their pooled data. The responses of the three yields were positive and significant by raising of $\mathrm{P}$ level from 15 to 30 and up to $45 \mathrm{~kg} \mathrm{P}_{2} \mathrm{O}_{5} /$ fad. These responses are in a good line with those reported by Sakr et al. (1996), and Maha Abd Alla (2004).

Concerning the interaction effect of irrigation interval and $\mathrm{K}$ fertilization levels on seed yield /fad. The results in Table (4a) showed that shortening irrigation interval from 8 to 6 and to 4 days increased significantly seed yield /fad. This was always true under studied any $\mathrm{K}$ fertilizer level. Also, under all irrigation intervals studied, any increase in $\mathrm{K}$ fertilizer level was followed by a significant respective increase in seed yield /fad.

Table 4-a: Effect of interaction between irrigation intervals and $\mathrm{K}$ fertilization levels on peanut seed yield $(\mathrm{kg} / \mathrm{fad})$.

\begin{tabular}{cccc}
\hline K-fertilizer levels & & & \\
Irrigation interval & $\mathbf{K}_{\mathbf{1}}$ & $\mathbf{K}_{\mathbf{2}}$ & $\mathbf{K}_{\mathbf{3}}$ \\
\hline $\mathbf{I}_{\mathbf{1}}$ & $\mathrm{C}$ & $\mathrm{B}$ & $\mathrm{A}$ \\
& $376.17 \mathrm{c}$ & $450.33 \mathrm{c}$ & $503.62 \mathrm{c}$ \\
$\mathbf{I}_{\mathbf{2}}$ & $\mathrm{C}$ & $\mathrm{B}$ & $\mathrm{A}$ \\
& $463.43 \mathrm{~b}$ & $536.12 \mathrm{~b}$ & $590.05 \mathrm{~b}$ \\
$\mathbf{I}_{\mathbf{3}}$ & $\mathrm{C}$ & $\mathrm{B}$ & $\mathrm{A}$ \\
& $545.48 \mathrm{a}$ & $663.93 \mathrm{a}$ & $728.03 \mathrm{a}$ \\
\hline
\end{tabular}

The interaction effect of both irrigation and phosphorous factors Table (4b) on foliage yield was significant, but no further information more than those got from the main effects of irrigation interval and $\mathrm{P}$ fertilization levels could be obtained. 
Table 4-b: Effect of interaction between irrigation intervals and Pfertilization levels on peanut foliage yield $(t / f a d)$.

\begin{tabular}{cccc}
\hline P-fertilizer levels & & & \\
Irrigation interval & $\mathbf{P}_{\mathbf{1}}$ & $\mathbf{P}_{\mathbf{2}}$ & $\mathbf{P}_{\mathbf{3}}$ \\
\hline $\mathbf{I}_{\mathbf{1}}$ & $\mathrm{C}$ & $\mathrm{B}$ & $\mathrm{A}$ \\
& $3.98 \mathrm{~b}$ & $4.71 \mathrm{~b}$ & $4.98 \mathrm{~b}$ \\
$\mathbf{I}_{\mathbf{2}}$ & $\mathrm{B}$ & $\mathrm{A}$ & $\mathrm{A}$ \\
& $4.67 \mathrm{a}$ & $4.92 \mathrm{~b}$ & $5.21 \mathrm{~b}$ \\
$\mathbf{I}_{\mathbf{3}}$ & $\mathrm{B}$ & $\mathrm{A}$ & $\mathrm{A}$ \\
& $4.90 \mathrm{a}$ & $5.40 \mathrm{a}$ & $5.65 \mathrm{a}$ \\
\hline
\end{tabular}

\section{5- Seed quality:}

Being an important in oil crop, both oil \% (for oil) and protein $\%$ (for cake) are important criteria in seed quality.

The results in Table (5) showed that, irrigation every 6 days caused a significant decrease in seed oil percentage. This was true in the second season and the combined. Shortening irrigation interval from 8 days decreased significantly protein percentage in the first season whereas, in the second season there is no significant effect. Similar findings were noted by Sakr et al. (1996).

Concerning $\mathrm{K}$ fertilization effect on seed oil percentage, it could be noted that, any increment of $\mathrm{k}$ fertilizer above $24 \mathrm{~kg} \mathrm{~K} 2 \mathrm{O} /$ fad was followed by a significant increase in seed oil percentage. This was true in both seasons and their combined. Similar results were obtained by Ali and Mowafy (2003) and Maha Abd Alla (2004).

The highest protein percentage in peanut seeds was recorded by appling of $72 \mathrm{~kg} \mathrm{~K}_{2} \mathrm{O} / \mathrm{fad}$. Similar findings were reported by Nasr-Alla et al. (1998) and Saleh et al. (2003). Meanwhile, there is no significant difference in protein percentage when plants were received 24 and $48 \mathrm{~kg} \mathrm{~K}_{2} \mathrm{O} / \mathrm{fad}$ in the second season and combined data.

The effect of phosphorus fertilizer was also significant in this respect. Favourable and significant effect of $\mathrm{P}$ application on both oil and protein contents of peanut seeds was recorded. The response was significant by application of $45 \mathrm{~kg} \mathrm{P}_{2} \mathrm{O}_{5} /$ fad in the first season and combined. Similar results were obtained by Ali and Mowafy (2003) and Maha Abd Alla (2004).

\section{6- Correlation studies:}

Data of simple correlation coefficients between seed yield of peanut and its contributing characters are presented in Table 6 . Seed yield appeared 
positive and significant correlation coefficients with all studied characters, except protein percentage had a positive and insignificant correlation coefficient with seed yield/ fad. Ali and Mowafy (2003) and Maha Abd Alla (2004) found that peanut seed yield/fad appeared positive and significant correlation coefficients with each of plant height, number of branches/plant, number of pods/plant, seed yield/plant, 100 -seed weight, shelling percentage and pod and foliage yields/fad. Also, all correlation coefficients among the studied yield attributes were positive and significant, except that of number of pods/plant with foliage yield/fad, shelling percentage with oil percentage and protein percentage with each of plant height, number of branches/plant, 100pod weight, shelling percentage and pod yield/fad, whereas coefficients did not reach the $5 \%$ level of significance.

Conclusively, from this study it could be concluded that peanut grown on sandy soil must be irrigate every four days and fertilized by at least $\mathrm{K}$ and $\mathrm{P}$ fertilizers. Previous analysis of soil shows that $\mathrm{K}$ and $\mathrm{P}$ contents of the experimental soil fall far below adequacy. Though peanut is a legume yet it needed $72 \mathrm{~kg} \mathrm{~K}_{2} \mathrm{O}$ and $45 \mathrm{~kg} \mathrm{P}_{2} \mathrm{O}_{5} / \mathrm{fad}$ under the same conditions.

\section{REFERENCES}

A.O.A.C (1980). Official Methods of Analysis. (13 ${ }^{\text {th }}$ ed.) Association of Official Analytical Chemists. Washington, D.C.

Ali, A. G. and Mowafy, S. A. E. (2003). Effect of different levels of potassium and phosphorus fertilizers with the foliar application of zinc and boron on peanut in sandy soil. Zagazig Journal of Agriculture Research, 30 (2): $335-358$.

Amir, Y.; T.Benblkacem; Hadni, L. and Youyou, A. (2005). Effect of irrigation and fertilization on the characteristics of peanut seeds cultivated near Tizi-Ouzou. Electronic Journal of Environmental Agricultural and Food Chemistry, 4 (2): 879-885.

Anton, N.A. and Bassiem, M. M. (1998). Effect of phosphorus and potassium fertilizers and foliar spray with ascorbic and citric acids on peanut plant under sandy soil conditions. Zagazig Journal of Agriculture Research, 25 (5): 733- 742.

Ash-Shormillesy-Salwa M. A. and Abd El-Hameed, I. M. (2005). Effect of some agricultural practices on productivity of peanut under sandy soil conditions. Zagazig Journal of Agriculture Research, 33 (4): 631 - 644. 
Asmaa Khameis, A. M. (2003). Effect of some agronomic treatments on yield and seed quality of peanut (Arachis hypogaea, L.). M. Sc. Thesis, Faculty Agriculture, Zagazig University, Egypt.

Attia, K. K. (2004). Response of two peanut varieties to phosphorus fertilization and foliar application of certain micronutrients under sandy calcareous soil conditions. Assiut Journal of Agriculture Science, 2 (4): 534-551.

Azab, A.M.; El-Raies, A. A. M. and Sawy, W.A. (2004). Effect of soil moisture and nitrogen fertilizer levels on water requirements and yield of peanut. Egyptian Journal of Applied Science, 14 (1): 103-114.

Dahdouh, M. M. (1999). Effect of K-fertilization, sulfur and spray of calcium chelate on peanut (Arachis hypogaea, L.) in a newly reclaimed soil. Zagazig Journal of Agriculture Research, 26 (2): 546 - 567.

Darwish, D.S.; El-Gharreib, A.; El-Hawary, M.A. and Rafft, G.A. (2002). Effect of some macro and micronutrients application on peanut production in a saline soil in El-Faiyum Governorate. Egyptian Journal of Applied Science, 17 (4): 17 - 32.

Desai, N.D.; Raman, S. and Joshi, R.S. (1992). Quality of groundnut as affected by irrigation, varieties and their interaction. Journal Soc. Soil Science, 40 (2): $358-360$.

Duncan, B.D. (1955). Multiple range and multiple F-test. Biometrics, 11:1-42.

El-Far, I.A. and Ramadan, B.R. (2000). Response of yield, yield components and quality of peanut (Arachis hypogaea, L.) to plant density and PK fertilization in sandy calcareous soil. Proceeding $9^{\text {th }}$ Conference Agronomy, Minufiya University, 1-2 Sept.: 453 - 466.

El-Shahat, A.M. (2001). Effect of planting density, phosphorus and foliar application on growth, yield and root system of groundnut in newly cultivated land. M.Sc. Thesis, Faculty of Agriculture, Zagazig University, Egypt.

Maha M. Abd Alla (2004). Effect of certain agricultural practices on productivity of peanut. 1- Influence of sowing dates and potassium application on yield and yield attributes of some penut cultivars. Zagazig Journal of Agriculture Research, 31 (3): 843 - 866.

Migawer A. Ekram and Mona A.M. Soliman (2001). Performance of two peanut cultivars and their response to NPK fertilization in newly reclaimed loamy sandy soil. Journal of Agriculture Science, Mansoura University., 26 (11): 6653 - 6667. 
Mirvat E. Gobarah; Magda H. Mohamed and Tawfik, M.M. (2006). Effect of phosphorus fertilizer and foliar spraying with zinc on growth, yield and quality of groundnut under reclaimed soil. Journal of Applied Science Research, 2 (8): 491 - 496.

Nasr-Alla, A.E.; Osman, F.A.A. and Soliman, K.G. (1998). Effect of increased phosphorus, potassium or sulfur application in their different combinations on yield, yield components and chemical composition of peanut in a newly reclaimed sandy soil. Zagazig Journal of Agriculture Research, 25 (3): 557 - 579.

Plout, Z. and Ben -Hur, M. (2005). Irrigation management of peanut with a moving sprinkler system: Runoff, yield and water use efficiency. Agronomy Journal, 97: 1202 - 1209.

Reddy, S.R.; Chalam, P.S.; Reddy, G.H.S. and Roju, A.P. (1982). Effect of irrigation frequency and nitrogen on groundnut yield and nutrient uptake. Plant and Soil, 65 (2): 257 - 263.

Sakr, M.M.; Ali, E.A. and Abd El-Mottaleb, H.M. (1996). Effects of irrigation intervals, nitrogen and phosphorus fertilization on leaf anatomical structure, chemical composition, yield and yield components of peanut (Arachis hypogaea, L.). Proceeding $7^{\text {th }}$ Conference Agronomy, Mansoura University, Egypt, 11: 391- 408.

Saleh, M.E.; Ramadan, L.E.; Ali, R.M. and Asmaa A. Khameis (2003). Effect of some agronomic treatments on yield and yield components. Zagazig Journal of Agriculture Research, 30 (6): 2071-2093.

Shinde, G.G. and Pawar, K.R. (1982). Effect of irrigation on the pod yield of groundnut. Indian Journal of Agriculture Science, 52 (9): 576- 578.

Shinde, G.G. and Pawar, K.R. (1984). Effect of water stress at critical growth stages on growth and yield of groundnut in summer season. Journal of Maharashtra Agriculture University, 9 (1): 26-28.

Snedecor, G.W. and Cochran, W.G. (1982). Statistical Methods Applied to Experiments in Agriculture and Biology. $7^{\text {th }}$ ed. Iowa State Collage. Amer. Iowa, USA.

Svab, J. (1973). Biometrial modszerek a Kutatas ban-Mezo-gazdassagi kiado, Budapest (C.F. Sunflower Conference, July, Novi Sad, Vol. 1: 423 428).

Yasein, M.A.T. (2005). Some factors affecting yield and seed quality of peanut (Arachis hypogaea, L.) M. Sc. Thesis, Faculty Agriculture, Zagazig University, Egypt. 
تأثير فترات الري ومعدلات التسميد الفوسفاتي والبوتاسى على الفول السوداني تحت ظروف الأراضي الرملية

مجدي فتحي عبد المقصود- عبد الغنى عبد المعطى منصور - أمين هاثم بسيونى

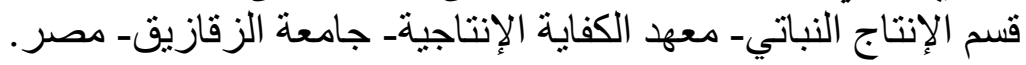

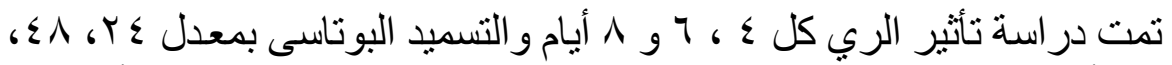

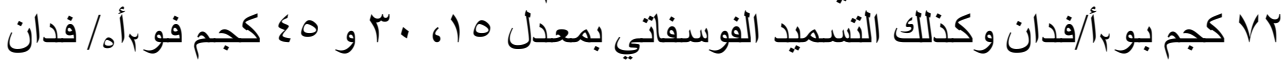

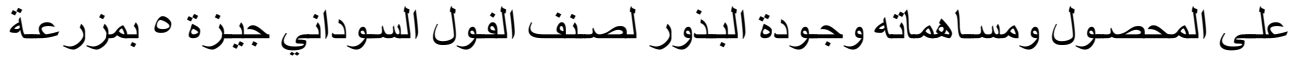

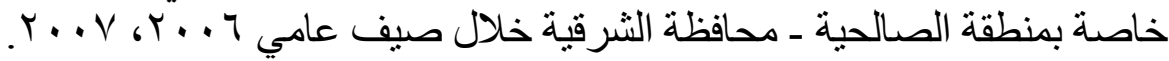

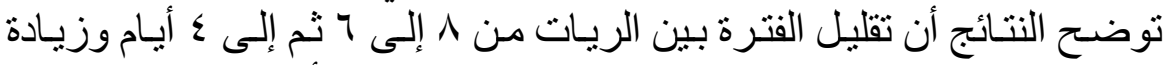

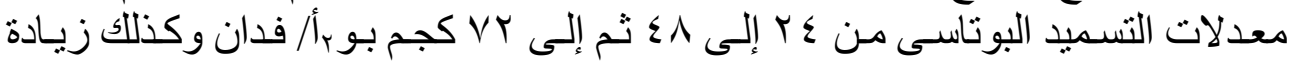

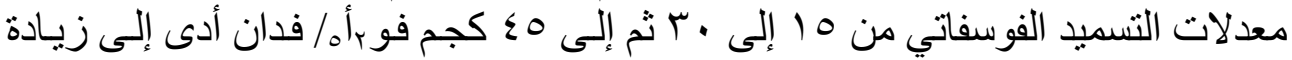

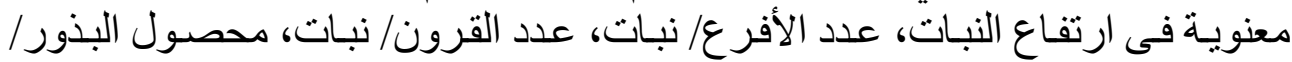

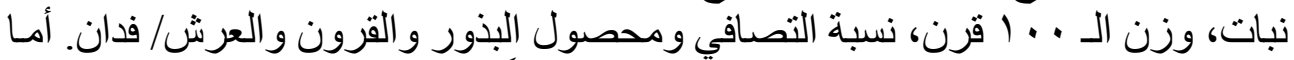

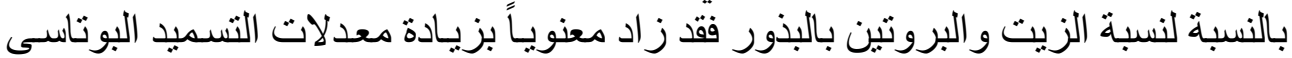

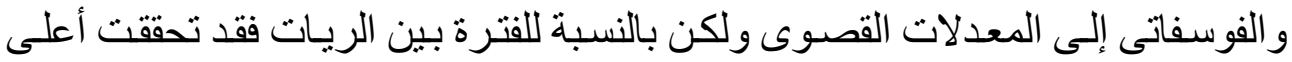

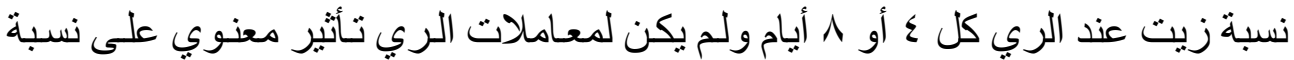

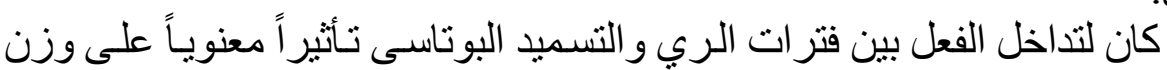

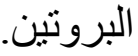

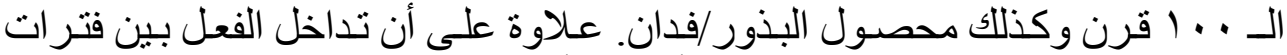

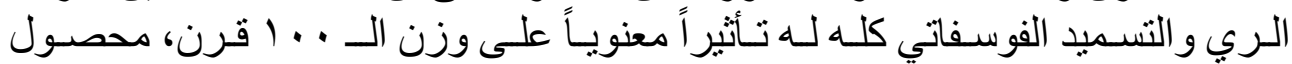

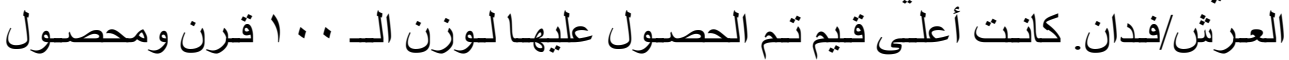

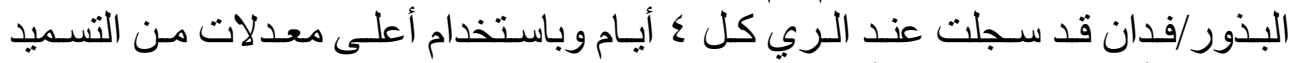

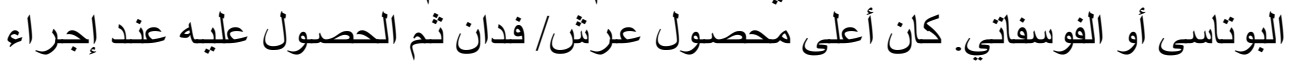

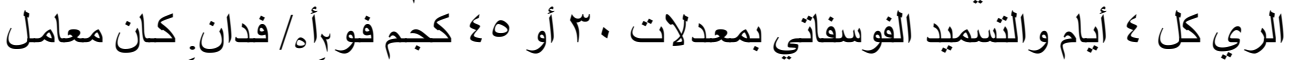

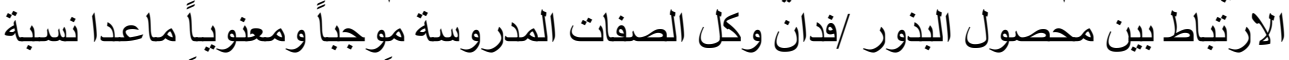

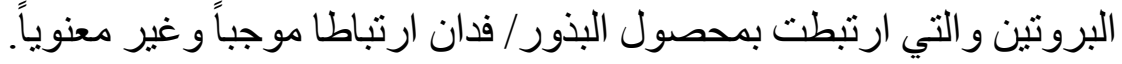

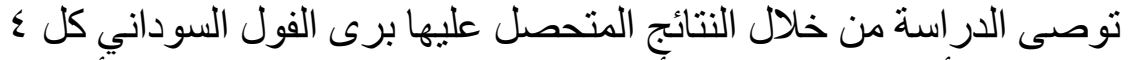

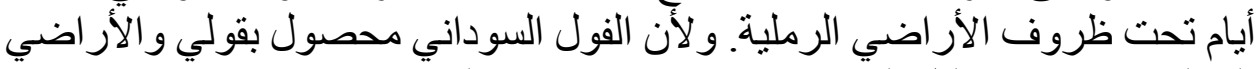

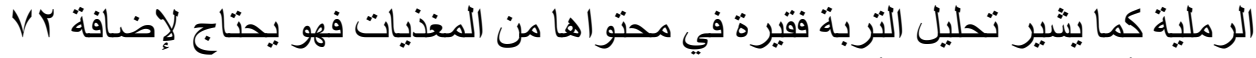
كجم بوبأ و هـ كجم فو بأه/فدان. 